\title{
The effect of \\ uncooked and roll-dried wheat starch, alone and mixed in equal quantity with sucrose, on dental caries in the albino rat
}

\author{
By R. M. GREEN AND R. L. HARTLES \\ Department of Dental Sciences, School of Dental Surgery, \\ University of Liverpool
}

(Received 25 May 1967 -Accepted 27 Fune 1967)

\begin{abstract}
I. Eighty weanling albino rats, five from each of sixteen litters were distributed between five dietary groups in sixteen randomized blocks. Each block was formed from within a litter and each animal in the block received a different diet.

2. The main features of the diets were: group I, $72 \%$ sucrose; group $2,72 \%$ uncooked wheat starch; group 3,72\% roll-dried wheat starch; group 4, 36\% sucrose and $36 \%$ uncooked starch; group 5, 36\% sucrose and 36\% roll-dried starch.

3. The rats were killed after 20 days on the diets and assessed for dental caries. The rats consuming diets containing sucrose (groups 1,4 and 5) had significantly more caries than animals receiving diets in which starch was the sole carbohydrate. The diet containing rolldried wheat starch produced significantly more caries than uncooked starch. The mixture of uncooked starch and sucrose was more cariogenic than the mixture of roll-dried starch and sucrose.
\end{abstract}

It has been shown (Green \& Hartles, I967) that rats fed on a diet containing sucrose as the sole source of carbohydrate had a greater caries incidence than those fed on diets containing a similar quantity of either uncooked or roll-dried maize starch. Sucrose diets were also more cariogenic than diets containing equal amounts of sucrose and either of the two forms of maize starch. The roll-dried maize starch produced significantly more caries than the uncooked starch. Somewhat surprisingly it was found that a mixture of sucrose and uncooked maize starch produced significantly more caries than a mixture of sucrose and roll-dried maize starch.

Grenby (1965) reported that he could not demonstrate any significant difference in caries incidence in Wistar rats receiving diets containing either uncooked or cooked wheat starch. The total consumption of maize starch in Britain is very small compared with that of wheat starch. In view of this and the findings of Grenby (1965) it was decided to repeat our earlier studies in which maize starch had been used but in this case to substitute wheat starch for maize.

\section{EXPERIMENTAL}

Eighty weanling albino rats of both sexes, five from each of sixteen litters, were assigned, one from each litter, to the five dietary groups. The animals were housed and managed as described by Green \& Hartles ( $1966 a, b$ ). The rats were weighed at the beginning, and at the end of the experiment. They were maintained on the diets for 20 days and then killed by diethyl ether inhalation. 


\section{Diets}

Diet RC I 4 (group I) contained $72 \%$ sucrose in the form of icing sugar (Green \& Hartles, $1966 b)$.

Diet RC 27 (group 2) was as RC I4 except that sucrose was replaced by uncooked wheat starch (Energen Limited).

Diet RC 28 (group 3) was as RC I4 except that sucrose was replaced by roll-dried wheat starch (Energen Limited).

Diet $\mathrm{RC} 29$ (group 4) was as $\mathrm{RC} \mathrm{I}_{4}$ except that half the sucrose was replaced by uncooked wheat starch.

Diet $\mathrm{RC}_{30}$ (group 5) was as $\mathrm{RC}_{\text {I4 }}$ except that half the sucrose was replaced by roll-dried wheat starch.

The diets and deionized water were provided in unrestricted amounts.

Dental caries was assessed as described by Green $\&$ Hartles (1966a).

\section{RESULTS}

Growth of animals. The animals remained healthy throughout the experiment and grew normally.

Caries incidence. The results are given in Table $\mathrm{I}$; dental caries is expressed as the number of lesions per rat in the first and second mandibular molars. Cumulative $T$

Table I. Caries experience of five groups each of sixteen rats maintained on different high-carbohydrate diets for 20 days

\begin{tabular}{|c|c|c|c|}
\hline Group & Diet & $\begin{array}{c}\text { Cumulative } \mathbf{T} \\
\text { (all lesions). } \\
\text { Mean }\end{array}$ & $\begin{array}{c}\text { Cumulative B } \\
\text { (more severe lesions). } \\
\text { Mean }\end{array}$ \\
\hline I & $\mathrm{RC}_{\text {I4 }}$, sucrose & $7 \cdot 2$ & $2 \cdot 1$ \\
\hline 2 & $\begin{array}{l}\mathrm{RC}_{27} \text {, uncooked } \\
\text { wheat starch }\end{array}$ & 0.9 & o \\
\hline 3 & $\begin{array}{l}\mathrm{RC}_{28} 8, \text { roll-dried } \\
\text { wheat starch }\end{array}$ & $3 \cdot 2$ & O.I \\
\hline 4 & $\begin{array}{l}\mathrm{RC}_{29} \text {, sucrose and } \\
\text { uncooked starch }\end{array}$ & $8 \cdot I$ & $2 \cdot 2$ \\
\hline \multirow[t]{2}{*}{5} & $\begin{array}{l}\mathrm{RC}_{30}, \text { sucrose and } \\
\text { roll-dried starch }\end{array}$ & $6 \cdot 5$ & $I \cdot I$ \\
\hline & $\begin{array}{l}\text { Pooled standard error } \\
\text { of group means }\end{array}$ & \pm 0.40 & $\pm 0.3 \mathrm{I}$ \\
\hline
\end{tabular}

includes all lesions (maximum value is 12 ), and cumulative $B$ includes the more severe lesions (see Green \& Hartles (1966a) for description of classification).

The total number of lesions present was subjected to an analysis of variance in which the total variation of the experiment was divided into that due to treatments, that due to blocks, and the residual or error variation. The total treatment variation was then further divided into a series of orthogonal comparisons so that each comparison could be given a valid level of significance, using Snedecor's $F$-test. The 
within-litter comparisons which have been made together with their levels of significance are shown in Table 2. The comparisons permit the following conclusions.

(I) Diets containing sucrose were significantly more cariogenic than those containing starch alone.

(2) Roll-dried wheat starch produced significantly more caries than uncooked starch.

(3) The mixture of uncooked wheat starch and sucrose was significantly more cariogenic than the mixture of roll-dried starch and sucrose.

Table 2. Within-litter comparisons of the total number of carious lesions arising as a result of different dietary carbohydrates, with the significance level for each comparison

(The number of rats compared is shown in parentheses)

\begin{tabular}{|c|c|c|c|}
\hline \multicolumn{3}{|c|}{ Dietary treatments compared } & $\begin{array}{l}\text { Level of } \\
\text { significance }\end{array}$ \\
\hline $\begin{array}{l}\text { Pure starches. } \\
\text { Groups } 2 \text { and } 3 \text { (32) }\end{array}$ & against & $\begin{array}{l}\text { diets containing sucrose. } \\
\text { Groups } 1,4 \text { and } 5(48)\end{array}$ & $P<0.001$ \\
\hline $\begin{array}{l}\text { Uncooked starch. } \\
\text { Group } 2(16)\end{array}$ & against & $\begin{array}{l}\text { roll-dried starch. Group } 3 \\
\text { (I6) }\end{array}$ & $P<0.001$ \\
\hline Sucrose. Group I (I6) & against & $\begin{array}{l}\text { sucrose/starch mixtures. } \\
\text { Groups } 4 \text { and } 5 \text { (32) }\end{array}$ & NS \\
\hline $\begin{array}{l}\text { Sucrose and uncooked } \\
\text { starch. Group } 4 \text { (I6) }\end{array}$ & against & $\begin{array}{l}\text { sucrose and roll-dried starch. } \\
\text { Group } 5 \text { (I6) }\end{array}$ & $P<0.025$ \\
\hline
\end{tabular}

\section{DISCUSSION}

In the production of dental caries wheat starch behaves in a similar manner to maize starch when incorporated in the diet of the caries-susceptible rat.

Diets containing uncooked wheat starch resulted in a low incidence of dental caries, and the roll-drying of the starch significantly increased its cariogenicity. However, the really intriguing finding was that a diet containing equal quantities of sucrose and uncooked starch was more cariogenic than one containing the same amounts of sucrose and roll-dried starch. This result is similar to that obtained with maize starch (Green \& Hartles, I967) and poses the interesting question as to why the consumption of a mixture of highly cariogenic sucrose with a virtually non-cariogenic starch should lead to more dental caries than when sucrose is mixed with moderately cariogenic roll-dried starch. We suggested earlier (Green \& Hartles, 1967) that in the case of roll-dried maize starch there may be present other metabolizable substrates which might lessen the utilization of sucrose by the flora of the dental plaque, but so far we have not obtained any evidence to support this view. We are now establishing techniques to determine the frequency of eating of rats on different diets, for this may prove to be a factor in the relative cariogenicity of diets.

Our finding that roll-drying of wheat starch increases its cariogenicity is apparently in conflict with results obtained by Grenby ( $\left.19^{6} 5\right)$. He prepared samples of precooked starch in his own laboratory and the resulting material was probably different 
from that produced by commercial roll-drying. These results focus attention on the possible effects of methods of processing on the caries-producing potential of starches.

We wish to thank Miss B. M. Morrison for her skilled technical assistance, the Medical Research Council for their financial support and Messrs Tate and Lyle Limited for the gift of icing sugar.

\section{REFERENCES}

Green, R. M. \& Hartles, R. L. (1966a). Br. F. Nutr. 20, 31 7.

Green, R. M. \& Hartles, R. L. (I966b). Archs oral Biol. 1r, 913.

Green, R. M. \& Hartles, R. L. (I 967). Br. F. Nutr. 2r, 225.

Grenby, T. H. (1965). Archs oral Biol. ro, 433. 